\title{
Bacteroides fragilis Group
}

National Cancer Institute

\section{Source}

National Cancer Institute. Bacteroides fragilis Group. NCI Thesaurus. Code C86173.

A bacterium that belongs to the Fragilis group of the genus Bacteroides. 